\begin{tabular}{c}
\hline TÜRK \\
TARIM ve DOĞA BiLIMLERI \\
DERGISi \\
\hline \hline
\end{tabular}

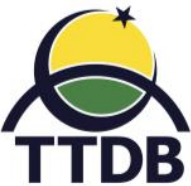

www.dergipark.gov.tr/turkjans

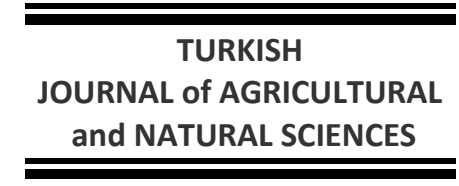

Araştırma Makalesi

\title{
Durum Buğdayın Başaklanma Dönemine ait Bazı Fizyolojik Ölçümlerin Verim ve Kalite Özellikleriyle ilişkilerinin Belirlenmesi
}

\author{
Ferhat KIZILGEÇi ${ }^{1 *}$, Mehmet YILDIRIM²
}

${ }^{1}$ Mardin Artuklu Üniversitesi, Kızıltepe Meslek Yüksek Okulu, Tohumculuk Bölümü, Mardin, Türkiye

${ }^{2}$ Dicle Üniversitesi, Ziraat Fakültesi, Tarla Bitkileri Bölümü, Diyarbakır, Türkiye

*Sorumlu yazar: ferhatkizilgeci@artuklu.edu.tr

Geliş Tarihi: 09.04.2019

Düzeltme Geliş Tarihi: 26.08.2019

Kabul Tarihi: 27.08.2019

\section{Özet}

Son yıllarda birçok araştırmacı spektral yansıma aletlerini buğday bitkisinin bazı gelişim dönemlerinde tane verimi ve kalite özellikleri arasındaki ilişkiyi belirlemede yoğun bir şekilde kullanmaktadır. Bu araştırma durum buğday genotiplerinin başaklanma döneminde bazı spektral yansıma aletleri ile ölçülen değerler ile tane verimi ve kalite özellikleri arasındaki ilişkinin belirlenmesi amacıyla 2015-16 ve 2016-17 üretim sezonu boyunca Şırnak ekolojik şartlarında yürütülmüştür. Çalışmada materyal olarak 2 ticari çeşit (Cesare ve Fırat 93) ve 7 adet ileri kademedeki durum buğday genotipi kullanılmıştır. İstatistik analiz sonucuna göre, incelenen özelliklerin yıl, genotip ve yıl x genotip interaksiyonu önemli farklılıklar bulunmuştur. Araştırmada incelenen, tane verimi 393.20-604.45 kg da-1, bin tane ağırlığı 22.98-47.96 g, hektolitre ağırlığı 75.4-85.8 kg hl-1, protein içeriği \% 14.9620.45, yaş gluten \% 27.36-47.55, nişasta içeriği \%59.3-63.24, irmik rengi (b) değeri 14.65-16.53, klorofil içeriği (SPAD) 45-53.58, bitki örtü sıcaklığı (BÖS) 21.5-27.3, normalize edilmiş vejetasyon farklılıkları indeksi (NDVI) değeri 0.42-0.85 ve yaprak alan indeksi (LAI) değeri 2.85-3.68 değerleri arasında değişim göstermiştir. Makarnalık buğdayın başaklanma döneminde ölçülen fizyolojik ölçümler ile tane verimi ve kalite özellikleri arasındaki ilişkiler yıllara göre farklılık göstermiştir. 2015-16 ve 2016-17 üretim sezonlarında ölçülen SPAD değeri ile protein içeriği ve yaş gluten arasında olumlu ilişkiler bulunması SPAD'ın ıslahta kaliteli genotip geliştirmede seleksiyon kriteri olarak değerlendirilebileceğini ve bu yönde daha kapsamlı araştırmalar yapılması gerektiğini düşündürmektedir.

Anahtar kelimeler: Buğday, bitki örtüsü sıcaklığı, SPAD, yaprak alan indeksi.

\section{The Relationship of Some Physiological Traits measured at Heading Stage with Yield and Quality properties of Durum Wheat}

\begin{abstract}
In recent years, many researchers have been using the spectral reflectance instruments intensively in determining the relationship between grain yield and quality traits in some development stages of wheat. This research was carried out to determine the relationship between grain yield and quality traits with the physiological values measured by some spectral reflectance instruments at heading stage of durum wheat genotypes in Sirnak conditions during 2015-16 and 2016-17 growing season. In the study, 2 commercial varieties (Cesare and Firat 93) and 7 advanced durum wheat genotypes were used. According to the results of statistical analysis, significant differences were found in year, genotype and year $\mathrm{x}$ genotype interactions of the examined traits. The data obtained from the study was changed between $3932,0-6044,5 \mathrm{~kg} \mathrm{ha}^{-1}$ in grain yield, 22.98-47.96 $\mathrm{g}$ in thousand kernel weight, $75.4-85.8 \mathrm{~kg} \mathrm{hl}^{-1}$ in test weight, $14.96-20.45 \%$ in protein content, 59.3$63.24 \%$ in wet gluten, $27.36-47.55 \%$ in starch content, $14.65-16.53$ in semolina color $(b)$ value, $45-53.6$ chlorophyll content (SPAD), $21.5-27.3^{\circ} \mathrm{C}$ in canopy temperature (CT), 0.42-0.85 in normalized differences vegetation index (NDVI) value and 2.85-3.68 in leaf area index (LAI) value. The relationship between the physiological measurements with grain yield and quality traits of durum wheat at the heading stage has
\end{abstract}


showed differences between years. It was determined a positive relationship between SPAD and protein content and wet gluten in both years, and it is thought that more extensive studies should be done in order to evaluate SPAD as a selection criterion for development of high quality genotypes in this stage.

Key words: Wheat, canopy temperature, SPAD, leaf area index.

\section{Giriş}

Durum buğday veya makarnalık buğday (Triticum turgidum L. subsp. durum Desf.) Dünyada olduğu gibi ülkemizde daha çok makarna sanayinin talebini karşılamak için yaygın olarak yetiştirilmektedir. Ülkemizde makarnalık buğday yetiştiriciliği ekmeklik buğday'a göre daha sınırlı alanlarda yapıldığından dolayı üretim miktarı daha düşüktür. Türkiye'de 2017 yılında, 12 milyon dekar alanda 3.5 milyon ton durum buğday üretimi yapılmıştır (TÜiK, 2018). Güneydoğu Anadolu Bölgesi (GDAB) durum buğdayın gen merkezi oluşu (Ozkan ve ark., 2011) ve uygun çevre şartlarına sahip olması nedeniyle bölgede yoğun olarak yetiştiriciliği yapılmaktadır (Tekdal ve Yıldırım, 2017). Şırnak ilinde 2018 yılında, 281 bin dekar alanda 86 bin ton üretim yapılmıştır (TÜiK, 2018). Durum buğdayda veriminin yanı sıra durum buğdayın kullanım amacını belirleyen protein içeriği, glüten içeriği ve irmik rengi gibi özellikler sanayicilerin önem verdiği en önemli kalite unsurlardır. Küresel ısınmanın neden olduğu abiyotik stres (kuraklık, aşırı sıcaklık, tuzluluk vb.) faktörleri buğday verimini ve tahıl kalitesini olumsuz yönde etkilemektedir (Huseynova ve Rustamova, 2010). GDAB'de buğdayın tane doldurma döneminde ortaya çıkan yüksek sıcaklık verimi sınırlayan ve tane kalitesini etkileyen önemli etkenlerden bir tanesidir. Bu nedenle günümüzde buğday ıslahçıları, gelecekteki nesillerin besin ihtiyacını ve bu çevrelerde tahıl üretiminin devamlılığını sağlayacak yüksek verimli, kaliteli ve adaptasyon kabiliyeti yüksek çeşitler geliştirme çabasındadırlar (Lopes ve ark., 2012; Li ve ark., 2013; Kızılgeçi ve ark., 2015). Son yıllarda birçok araştırmacı tarafından buğday ıslah çalışmalarında klorofil içeriği (SPAD), yaprak alan indeksi (LAI) ve normalize edilmiş vejetasyon farklılık indeksi (NDVI) gibi spektral yansıma ölçüm aletleri ve bitki örtüsü sıcaklığını (BÖS) ölçen kızıötesi termometre kültür bitkilerinin tane verimi ve kalite özelliklerini belirlemede önemli bir seleksiyon aracı olarak kullanılmaktadır (Giunta ve ark., 2002; Yıldırım ve ark., 2009; Talebi, 2011; Islam ve ark., 2014; Kızılgeçi ve ark., 2017). Buğday bitkisi dünya genelinde bu tür fizyolojik ölçüm yapan cihazlar ile çalışılan en yaygın bitki türlerinden biridir. Islah çalışmalarında bu fizyolojik özellikleri ölçen aletlerin kullanılması çok sayıda genotipin hızlı ve etkin bir şekilde taranmasına imkan sağlamaktadır (Pinto ve ark., 2010; Schuhwerk, 2011) Bu araştırmada, Farklı üretim sezonlarında Şırnak ekolojik şartlarında durum buğday genotiplerinin başaklanma döneminde ölçülen bazı fizyolojik parametreler ile tane verimi ve bazı kalite özellikleri arasındaki ilişkinin incelenmesi ve Şırnak koşullarına uygun yüksek verim ve kaliteli genotiplerin belirlenmesi amaçlanmıştır.

Çizelge 1. 2015-16 ve 2016-17 yılları Şırnak illine ait meteorolojik veriler

\begin{tabular}{|c|c|c|c|c|c|c|}
\hline \multirow{2}{*}{ Aylar } & \multicolumn{2}{|c|}{ Ortalama Sıcaklık $\left({ }^{\circ} \mathrm{C}\right)$} & \multicolumn{2}{|c|}{ Yağış (mm) } & \multicolumn{2}{|c|}{ Nisbi Nem (\%) } \\
\hline & 2015-16 & 2016-17 & 2015-16 & 2016-17 & 2015-16 & 2016-17 \\
\hline Ekim & 17.5 & 19.7 & 34.2 & 50.2 & 60.9 & 42.8 \\
\hline Kasım & 8.5 & 11.5 & 97.6 & 112.9 & 70.2 & 50.8 \\
\hline Aralık & 6.6 & 8.4 & 73.4 & 109.1 & 87.9 & 70.9 \\
\hline Ocak & 2.2 & 5.2 & 64.6 & 60 & 80.9 & 64.1 \\
\hline Şubat & 5.4 & 6.7 & 55.2 & 111 & 80.6 & 66.8 \\
\hline Mart & 8.3 & 10.1 & 127 & 149.9 & 74.6 & 57.9 \\
\hline Nisan & 12.4 & 14.5 & 48.6 & 46.3 & 70 & 51 \\
\hline Mayıs & 18.7 & 22.5 & 48.2 & 49.7 & 58.1 & 33.4 \\
\hline Haziran & 26 & 28.5 & 7.4 & 3.7 & 36.1 & 24.2 \\
\hline Toplam/Ort. & 11.73 & 14.11 & 556.2 & 692.8 & 68.8 & 51.3 \\
\hline
\end{tabular}

\section{Materyal ve Yöntem}

Bitki materyali, çevresel şartlar ve arazi çalışması

$\mathrm{Bu}$ çalışmada Güneydoğu Anadolu

Bölgesinde yüksek verim ve geniş adaptasyon kabiliyetine sahip Cesare ve Fırat-93 durum buğday çeşitleri ve 7 adet ileri kademedeki makarnalık buğday genotipi kullanılmıştır. Çalışma 2015-16 ve
2016-17 yetiştirme sezonlarında Şırnak ilinde yürütülmüştür. Deneme sahasına ait toprak yapısının killi olduğu ve organik madde (\% 0.72) ve fosfor (1.14 kg da $\left.{ }^{-1}\right)$ miktarı düşük, tuzluluk sorunu olmayan (EC:0.85 dS $\mathrm{m}^{-1}$ ) ve $\mathrm{pH}$ değerleri 7.6 olan yerdir. Yağış yönünden çalışmanın yürütüldüğü dönemde toplam yağış miktarı 2015-16 sezonunda 
556,2 mm, 2016-17 sezonunda 692,8 mm olmuştur. Ortalama sıcaklık değeri 2015-16 sezonuna kıyasla 2016-17 sezonunda daha yüksek olduğu görülmüştür (Çizelge 1). Arazi çalışması her iki yılda Kasım ayında tesadüf blokları deneme desenine göre 4 tekrarlamalı olarak parsel alanı 4.8 $\mathrm{m}^{2}$ (4 m x $1.2 \mathrm{~m}$ ) olacak şekilde 6 sıralı deneme mibzeri ile ekim yapılarak kurulmuştur. Deneme alanına ekimle birlikte $6 \mathrm{~kg}$ saf $P$ ve $6 \mathrm{~kg}$ saf $\mathrm{N}$ gelecek şekilde 20:20 kompoze gübresi ve sapa kalkma döneminde ise dekara $6 \mathrm{~kg}$ saf $\mathrm{N}$ amonyum nitrat (\%33) formunda uygulanmıştır. Geniş yapraklı yabancı otlar, hastalık ve zararlılara karşı kimyasal mücadele yapılmıştır. Hasat işlemi parsel alanı $3.8 \mathrm{~m}^{2}$ olacak şekilde elle yapılmıştır.

\section{incelenen özellikler}

Tane verimi $(\mathrm{kg} / \mathrm{da})$ : Her parselin hasatharman edilmesiyle elde edilen verim değerlerinin dekara çevrilmesi sonucunda dekara kg olarak belirlenmiştir.

Hektolitre ağırlığı $\left(\mathrm{kg} \mathrm{hl}^{-1}\right)$, tanede protein içeriği (\%), yaş glüten içeriği (\%), tanede nişasta içeriği (\%): Buğday taneleri öğütülmeden NIT System Infratec 1241 Grain Analyzer (Foss) cihazıyla ölçülmüştür.

Bin tane ağırlığı (g): 4 adet 100'er tohum sayılmış ve bu tohumların tartım sonucunda elde edilen ortalamalar 10 ile çarpılarak bin tane ağırlığı belirlenmiştir.

Renk değerleri (b): buğday tanelerinin renk ölçüm değerleri HunterLab ColorFlex, cihazı ile ölçülmüştür.

Klorofil içeriği (SPAD): Bitkiler başaklanma döneminde iken her parselde rastgele seçilen 10 bitkinin bayrak yapraklarından SPAD metre (SPAD 502, Minolta) ile güneşli açık havada saat 11-13 arasında ölçüm yapılmış ve elde edilen değer SPAD birimi olarak ifade edilmiştir.

Bitki örtü sıcaklığı (BÖS): Fischer ve ark. (1998)'nın belirttiği yönteme göre Rothenbenger hassas-kızılötesi termometre ile ölçülmüştür.

Normalize edilmiş vejetasyon farklılık indeksi (NDVI): Bitkiler başaklanma döneminde iken elle taşınabilir, ölçümü kolay ve bitkiye zarar vermeyen Trimple Greenseeker ile ölçülmüştür.

Yaprak alan indeksi (LAI): başaklanma döneminde LAI-2000 (LI-COR, Lincoln, NE) yardımıyla her parsellin toprak seviyesinden iki ve sıranın üst kısmında 1 ölçüm alınarak belirlenmiştir.

\section{Verilerin Değerlendirilmesi}

Çalışma sonucunda elde edilen verilerin varyans analizi ve özellikler arası korelasyon ilişkisi JMP Pro 13 istatistiki paket programı ile yapılmış, ortalamalar arasında ortaya çıkan farklılıklar ise
LSD (\%5) çoklu karşılaştırma testine tabi tutulmuştur.

\section{Bulgular ve Tartışma \\ Tane verimi ve fiziksel özellikleri}

Durum buğday genotiplerinin tane verimi, bin tane ağırlığı ve hektolitre ağırlığına ait elde edilen sonuçlar Çizelge 2'de verilmiştir. Tane verimi ve bin tane ağırlığı bakımından genotip, yıl ve genotip $x$ yıl interaksiyonu istatistiki olarak \%1 düzeyinde önemli bulunmuştur. Hektolitre ağırlığında ise genotip ve yıllar arası farklılıklar önemli bulunurken, genotip $x$ yıl interaksiyonu önemsiz bulunmuştur. Tane verimi ilk yıl 393.20$530.09 \mathrm{~kg} \mathrm{da}^{-1}$ ve ikinci yıl 394.10-604.45 kg da-1 arasında değerlere sahip olmuştur. En yüksek tane verimi değeri ikinci yıl G7 hattında (604.45 kg da-1), en düşük tane verimi değeri ise birinci yıl G6 hattında $\left(393.20 \mathrm{~kg} \mathrm{da}{ }^{-1}\right)$ elde edilmiştir. Genotiplerin yıllar ortalamalarına göre en yüksek tane verimi değeri $548.76 \mathrm{~kg} \mathrm{da}^{-1}$ (Fırat 93), en düşük değer $393.65 \mathrm{~kg} \mathrm{da}^{-1}$ (G6) olduğu görülmüştür. Yıl ortalamalarına göre araştırmanın yürütüldüğü ikinci yılda elde edilen ortalama tane verimi değeri birinci yıla kıyasla daha yüksek bulunmuştur. 2016-17 yılında bitki gelişimi için önemli olan Mart-Mayıs dönemlerinde düşen toplam yağış miktarının yüksek oluşu tane verimine olumlu yönde etkiye sahip olmuştur. Kızılgeçi ve ark. (2015) yağışa dayalı koşullarda yetiştirilen buğdayın gelişim dönemleri boyunca düşen yağış miktarı tane verimini önemli derecede etkilediğini bildirmişlerdir. Hektolitre ağırlığı ve bin tane ağırlığı makarnalık buğdayın kalitesini belirleyen fiziksel faktörlerdir (Çölkesen, 1993). Bin tane ağırlığı özelliği 2015-16 ve 2016-17 yıllar itibariyle 34.1747.96 g ve 22.98-42.13 g arasında değerlere sahip olmuştur. 2016-17 üretim sezonunda genotiplerin ortalama bin tane ağırlığı değerleri 2015-16 üretim sezonuna göre daha geniş bir varyasyon gösterdiği görülmüştür. Genotiplerin yıl ortalamalarına göre en yüksek bin tane ağırlığı değeri Fırat 93 çeşidinde (42.08 g), en düşük değer ise G4 hattında (22.98 g) elde edilmiştir. Fırat 93 çeşidi ve G6 hattı ise her iki yılda en yüksek bin tane değerine sahip genotipler olmuşlardır. Hektolitre ağırlığı birinci yılda 79.70$85.80 \mathrm{~kg} \mathrm{hL}^{-1}$ ve ikinci yılda 75.4-84,18 $\mathrm{kg} \mathrm{hL}^{-1}$ değerleri aralığında değişim göstermiştir. Yıl ortalamalarına göre hektolitre ağırlığı en düşük G6 hattında (77.55 kg hL-1) en yüksek ise Fırat 93 çeşidinde $\left(84.51 \mathrm{~kg} \mathrm{hL}^{-1}\right)$ elde edilmiştir. Yıllar hektolitre ağırlığı yönünden kıyaslandığında 201516 sezonunda elde edilen ortalama değer 2016-17 sezonuna göre daha yüksek olduğu görülmüştür. Fırat 93 çeşidi her iki yılda tane verimi, bin tane ağırlığı ve hektolitre ağırlığı özellikleri yönünden ön plana çıkan genotip olmuştur. Araştırmamızda tane 
verimi ve tanenin fiziksel özellikleri üzerine genotip ve yıl etkisinin önemli olduğu görülmüştür. Önceki yapılan çalışmalarda, çevresel koşulların ve gübre uygulamalarının tane verimi ve tanenin fiziksel özellikleri üzerinde önemli etkiye sahip olduğunu bildirmiştir (Lopes ve ark., 2012; Mohammadi, 2012; Li ve ark., 2013; Bouacha ve ark., 2014; Kaya ve Akçura, 2014). Kılıç (2003), bin tane ağırlığı için genotip özelliğinin çevresel faktörlere kıyasla daha etkili olduğunu, bununla yanı sıra çevre $x$ genotip interaksiyonun da bin tane ağırlığı üzerinde etkili olduğunu rapor etmiştir. Mohammadi (2012), sıcaklık stresi altında yüksek bin tane ağırlığına sahip buğday çeşitlerinin sıcak çevrelerde daha fazla toleransa sahip olduğu ve Lopes ve ark. (2012) sıcak çevrede bin tane ağırlığı özelliğinin buğday genotiplerinin seleksiyonunda bir kriter olabileceğini.belirtmiştir.

Çizelge 2. Farklı yıllarda yetiştirilen dokuz durum buğday genotipine ait tane verimi, bin tane ağırlığı ve hektolitre ağırlıklarına ait ortalama değerleri

\begin{tabular}{|c|c|c|c|c|c|c|c|c|c|}
\hline \multirow{2}{*}{ Genotip } & \multicolumn{3}{|c|}{ Tane Verimi $\left(\mathrm{kg} \mathrm{da}^{-1}\right)$} & \multicolumn{3}{|c|}{ Bin Tane Ağırlığı (g) } & \multicolumn{3}{|c|}{ Hektolitre Ağırlığı $\left(\mathrm{kg} \mathrm{hL}^{-1}\right)$} \\
\hline & 2015-16 & $2016-17$ & Ortalama & 2015-16 & 2016-17 & Ortalama & 2015-16 & 2016-17 & Ortalama \\
\hline CESARE & $482.78^{b}$ & $552.50^{\mathrm{a}-\mathrm{d}}$ & $517.64^{\mathrm{ab}}$ & $39.18^{b}$ & $33.14^{c}$ & $36.16^{c}$ & 84.97 & 83.49 & $84.23^{\mathrm{ab}}$ \\
\hline FIRAT93 & $530.09^{a}$ & $567.43^{\mathrm{abc}}$ & $548.76^{a}$ & $47.48^{a}$ & $42.08^{a}$ & $44.78^{a}$ & 84.83 & 84.18 & $84.51^{\mathrm{a}}$ \\
\hline G1 & $432.85^{d}$ & $483.96^{\mathrm{cd}}$ & $458.40^{c}$ & $34.17^{c}$ & $27.56^{d}$ & $30.87^{\mathrm{de}}$ & 85.8 & 81.62 & $83.71^{\mathrm{ab}}$ \\
\hline G2 & $458.13^{c}$ & $479.45^{\text {de }}$ & $468.79^{c}$ & $37.28^{\mathrm{bc}}$ & $27.84^{d}$ & $32.56^{d}$ & 83.94 & 80.81 & $82.37^{\mathrm{ab}}$ \\
\hline G3 & $444.31^{c d}$ & $525.62^{\mathrm{a}-\mathrm{d}}$ & $484.97^{b c}$ & $35.67^{c}$ & $28.07^{d}$ & $31.87^{d}$ & 84.31 & 80.13 & $82.22^{\mathrm{ab}}$ \\
\hline G4 & $478.40^{\mathrm{b}}$ & $490.00^{\mathrm{bcd}}$ & $484.20^{\mathrm{bc}}$ & $35.14^{c}$ & $22.98^{e}$ & $29.06^{e}$ & 85.44 & 79.70 & $82.57^{\mathrm{ab}}$ \\
\hline G5 & $406.18^{e}$ & $574.93^{\mathrm{ab}}$ & $490.56^{b c}$ & $47.96^{a}$ & $36.94^{b}$ & $42.45^{b}$ & 83.97 & 81.35 & $82.66^{a b}$ \\
\hline G6 & $393.20^{\mathrm{e}}$ & $394.10^{\mathrm{e}}$ & $393.65^{d}$ & $46.65^{a}$ & $42.13^{\mathrm{a}}$ & $44.39^{a}$ & 79.7 & 75.40 & $77.55^{c}$ \\
\hline G7 & $442.08^{\text {def }}$ & $604.45^{\mathrm{a}}$ & $523.27^{\mathrm{ab}}$ & $40.38^{b}$ & $33.22^{c}$ & $36.80^{c}$ & 83.42 & 80.88 & $82.15^{b}$ \\
\hline Ortalama & $452.00^{\mathrm{b}}$ & $519.16^{a}$ & 485.58 & $40.43^{a}$ & $32.66^{b}$ & 36.54 & $84.04 \mathrm{a}$ & $80.84 \mathrm{~b}$ & 82.44 \\
\hline$\overline{L S D(Y I l)}$ & & $20.43^{* *}$ & & & $0.88^{* *}$ & & & $1.10 * *$ & \\
\hline LSD(Genotip) & & $43.34 * *$ & & & $1.88^{* *}$ & & & $2.34 * *$ & \\
\hline LSD(Yı*Gen.) & & $61.29 * *$ & & & $2.66 * *$ & & & Öd & \\
\hline
\end{tabular}

*,** \%5 ve \%1 düzeyinde önemlidir. Öd: önemli değil, aynı harflerle gösterilen ortalamalar arasında farklılık yoktur.

Çizelge 3'te tane verimi ve tanenin fiziksel özellikleri ile fizyolojik parametreler ve kalite özellikleri arasındaki korelasyon analizi incelendiğinde, birinci yılda tane verimi ile hektolitre ağırlığı arasında $\left(r=0.385^{*}\right)$ olumlu önemli ilişki belirlenirken, BÖS arasında ( $r=-$ $0.573^{* *}$ ) olumsuz önemli ilişki belirlenmiştir. Bin tane ağırlığı ile protein içeriği ve yaş gluten ( $r=0.473^{* *}$ ve $0.709^{* *}$, sırasıyla) arasında olumlu ve önemli ilişki görülürken, hektolitre ağırlığı, SPAD ve $b$ değeri ile arasında olumsuz ve önemli ( $r=-$ $0.368^{*},-0.556 * *$ ve $-0.650 * *$, sırasıyla) ilişki görülmüştür. Hektolitre ağırlığı özelliği ile nişasta içeriği ile olumlu ve önemli $\left(r=0.602^{* *}\right)$ ilişki belirlenirken, protein içeriği, yaş gluten ve BÖS ile olumsuz ve önemli $(r=-0.340 *,-0.575 * *,-0.329 * *$, sırasıyla) ilişki belirlenmiştir. İkinci yılda tane verimi ile hektolitre ağırlığı ve nişasta içeriği $\left(r=0.516^{* *}\right.$, $0.488^{*}$, sırasıyla) arasında olumlu ve önemli ilişki belirlenirken, SPAD ile olumsuz ve önemli ( $r=-$ $0.367^{*}$ ) ilişki belirlenmiştir. Bin dane ağırlığı özelliği ile $b$ değeri arsında olumsuz ve önemli $\left(r=-0.828^{* *}\right)$ ilişki görülmüştür. Hektolitre ağırlığı ile nişasta içeriği ve $b$ değeri arasında olumlu ve önemli ilişki belirlenirken, protein içeriği, yaş gluten ve SPAD ile olumsuz önemli (sırasıyla, $r=-0.689 * *,-0.548 * *$, $0.456^{* *}$ ) ilişki görülmüştür.

\section{Kalite özellikleri}

2015-16 ve 2016-17 yıllarında yetiştirilen buğday genotiplerinin protein içeriği, yaş glüten, nişasta içeriği ve irmik rengi $(b)$ değeri Çizelge 4'te verilmiştir. İncelenen özellikler bakımından yıl ve genotip arasında farklılıklar istatistikî olarak önemli $(P \leq 0,01)$ bulunmuştur. Ayrıca, genotip $x$ yıl interaksiyonu tanede protein içeriği ve yaş gluten özelliği için \%1 düzeyinde önemli görülmüştür (Çizelge 4). Tanenin kalite özellikleri genotipin yanı sıra çevrenin etkisi altındadır (Yıldırım ve ark., 2018a).

Protein içeriği değeri tanenin son ürün kullanım amacını belirlemek için kullanılan önemli bir kalite kriteridir. Protein içeriği değerleri birinci yılda \%14.96-17.30 ve ikinci yılda \%16.99-20.45 arasında değişim göstermiştir. 2015-16 üretim sezonunda (\%16.21) elde edilen ortalama tanede protein içeriği değeri 2016-17 üretim sezonuna $(18,67)$ kıyasla daha düşük bulunmuştur. Genotiplerin yıl ortalamalarına göre en yüksek tanede protein içeriği değeri G6 hattında (\%18.87) en düşük ise G1 hattında (\%16.36) belirlenmiştir. Yaş glüten değeri birinci yılda \%27.83-33.22 değerleri arasında değişim gösterirken ikinci yılda \%40.15-47.55 arasında değerler almıştır. 
Türk Tarım ve Doğa Bilimleri Dergisi 6(4): 777-785, 2019

Çizelge 3. Her iki yılda durum buğdayın başaklanma döneminde ölçülen fizyolojik ölçümler ile tane verimi ve kalite özellikleri arasındaki korelasyon ilişkisi

2016-17 üretim sezonu

\begin{tabular}{|c|c|c|c|c|c|c|c|c|c|c|c|c|}
\hline \multirow{12}{*}{ 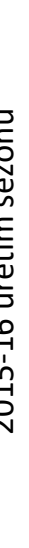 } & Özellikler & Tane verim & Bin tane ağırlığı & Hektolitre Ağırlığı & Protein İçeriği & Yaş gluten & Nişasta İçeriği & $b$ değeri & SPAD & BÖS & NDVI & LAI \\
\hline & Tane verimi & 1 & 0.095 & $0.511 * *$ & $-0.518 * *$ & $-0.587 * *$ & $0.488 * *$ & 0.001 & $-0.367^{*}$ & -0.282 & 0.181 & 0.234 \\
\hline & Bin tane ağırlığı & -0.104 & 1 & 0.031 & -0.232 & -0.015 & 0.203 & $-0.829 * *$ & -0.080 & -0.091 & 0.174 & -0.155 \\
\hline & Hektolitre & $0.385^{*}$ & $-0.369 *$ & 1 & $-0.689 * *$ & $-0.548 * *$ & $0.679 * *$ & $0.335^{*}$ & $-0.456 * *$ & -0.034 & 0.102 & 0.071 \\
\hline & Protein içeriği & -0.079 & $0.474 * *$ & $-0.406 *$ & 1 & $0.806 * *$ & $-0.753^{* *}$ & -0.021 & $0.596 * *$ & -0.151 & -0.261 & -0.216 \\
\hline & Yaş gluten & $-0.356^{*}$ & $0.709 * *$ & $-0.575 * *$ & $0.664 * *$ & 1 & $-0.594^{* *}$ & -0.125 & $0.733^{* *}$ & -0.140 & $-0.350 *$ & -0.227 \\
\hline & Nişasta içeriği & 0.020 & -0.213 & $0.603 * *$ & $-0.425^{* *}$ & $-0.429 * *$ & 1 & 0.148 & $-0.460 * *$ & -0.090 & 0.112 & -0.040 \\
\hline & bdeğeri & -0.048 & $-0.650 * *$ & 0.158 & $-0.330 *$ & -0.233 & -0.021 & 1 & -0.006 & -0.063 & -0.191 & 0.102 \\
\hline & SPAD & 0.168 & $-0.557 * *$ & 0.177 & 0.134 & $0.373 *$ & -0.203 & $0.422 *$ & 1 & -0.146 & $-0.440 * *$ & -0.093 \\
\hline & BÖS & $-0.574 * *$ & 0.078 & $-0.330 *$ & $0.384 *$ & 0.249 & -0.299 & -0.031 & 0.040 & 1 & $0.364^{*}$ & 0.088 \\
\hline & NDVI & -0.311 & -0.010 & -0.266 & 0.023 & 0.278 & -0.085 & $0.375^{*}$ & -0.186 & 0.117 & 1 & 0.178 \\
\hline & LAI & -0.033 & 0.281 & -0.099 & 0.305 & 0.230 & -0.249 & -0.065 & 0.066 & 0.243 & 0.022 & 1 \\
\hline
\end{tabular}

Çizelge 4. Farklı yıllarda yetiştirilen dokuz makarnalık buğday genotiplerinin protein içeriği, yaş gluten, nişasta içeriği, $b$ değeri

\begin{tabular}{|c|c|c|c|c|c|c|c|c|c|c|c|c|}
\hline \multirow{2}{*}{ Genotip } & \multicolumn{3}{|c|}{ Protein içeriği (\%) } & \multicolumn{3}{|c|}{ Yaş Glüten(\%) } & \multicolumn{3}{|c|}{ Nişasta içeriği(\%) } & \multicolumn{3}{|c|}{ İrmik rengi(b) değeri } \\
\hline & 2015-16 & 2016-17 & Ort. & 2015-16 & 2016-17 & Ort. & 2015-16 & 2016-17 & Ort. & 2015-16 & 2016-17 & Ort. \\
\hline CESARE & $15.75^{d}$ & $18.38^{\mathrm{bc}}$ & $17.06^{\text {cde }}$ & $29.90^{\text {ghl }}$ & $44.03^{c}$ & $36.96^{\mathrm{b}}$ & 62.37 & 60.56 & $61.46^{\mathrm{ab}}$ & 15.76 & 16.07 & $15.91^{b}$ \\
\hline FIRAT93 & $16.67^{\mathrm{ab}}$ & $16.99^{d}$ & $16.83^{\text {de }}$ & $31.07^{\mathrm{g}}$ & $40.47^{e}$ & $35.77^{c d}$ & 62.66 & 61.18 & $61.92^{\mathrm{a}}$ & 14.65 & 15.38 & $15.01^{d}$ \\
\hline G1 & $14.96^{\mathrm{e}}$ & $17.77^{\mathrm{cd}}$ & $16.36^{\mathrm{e}}$ & $27.36^{k}$ & $41.49^{\text {de }}$ & $34.42^{\mathrm{e}}$ & 63.24 & 60.63 & $61.93^{a}$ & 15.85 & 16.24 & $16.05^{\mathrm{at}}$ \\
\hline $\mathrm{G} 2$ & $16.45^{\mathrm{bc}}$ & $18.53^{b c}$ & $17.49^{\mathrm{bcd}}$ & $29.24^{h i j}$ & $42.27^{d}$ & $35.76^{\mathrm{cd}}$ & 62.09 & 60.32 & $61.21^{a b c}$ & 15.68 & 16.06 & $15.87^{b}$ \\
\hline G3 & $15.57^{\text {de }}$ & $19.23 a^{b}$ & $17.40^{\text {cd }}$ & $27.83^{\mathrm{jk}}$ & $42.75^{c d}$ & $35.29^{\mathrm{de}}$ & 62.69 & 59.88 & $61.29^{a b c}$ & 15.34 & 16.32 & $15.83^{b}$ \\
\hline G4 & $15.90^{\text {cd }}$ & $20.36^{a}$ & $18.13^{b}$ & $28.56^{\mathrm{jjk}}$ & $45.99^{b}$ & $37.27^{b}$ & 62.42 & 59.49 & $60.96^{\mathrm{bc}}$ & 16.12 & 16.53 & $16.32^{\mathrm{a}}$ \\
\hline G5 & $16.12^{\mathrm{bcd}}$ & $18.44^{\mathrm{bc}}$ & $17.28^{\mathrm{cd}}$ & $30.57^{\text {gh }}$ & $42.90^{\mathrm{cd}}$ & $36.73^{b c}$ & 62.75 & 60.82 & $61.78^{a}$ & 15.03 & 15.75 & $15.39^{c c}$ \\
\hline G6 & $17.30^{\mathrm{a}}$ & $20.45^{a}$ & $18.87^{a}$ & $33.22^{f}$ & $47.55^{a}$ & $40.38^{a}$ & 61.85 & 59.3 & $60.57^{c}$ & 15.27 & 14.96 & $15.11^{d}$ \\
\hline G7 & $17.20^{\mathrm{a}}$ & $17.88^{\mathrm{cd}}$ & $17.54^{\mathrm{bc}}$ & $30.80^{\mathrm{g}}$ & $40.15^{e}$ & $35.47^{\text {de }}$ & 62 & 61.08 & $61.54^{\mathrm{ab}}$ & 15.48 & 15.92 & $15.70^{\mathrm{bc}}$ \\
\hline Ortalama & $16.21^{b}$ & $18.67^{a}$ & 17.44 & $29.84^{b}$ & $43.07^{a}$ & 36.45 & $62.45^{\mathrm{a}}$ & $60.36^{b}$ & 61.40 & $15.46^{b}$ & $15.91^{\mathrm{a}}$ & 15.68 \\
\hline LSD(YII) & & $0.32 * *$ & & & $0.5^{* *}$ & & & $0.34 * *$ & & & $0.16^{* *}$ & \\
\hline LSD(Genotip) & & $0.7^{* *}$ & & & $1.08^{* *}$ & & & $0.72 * *$ & & & $0.36^{* *}$ & \\
\hline LSD(GenxYıl) & & $0.98 * *$ & & & $1.52^{* *}$ & & & öd & & & öd & \\
\hline
\end{tabular}

*, ** \%5 ve \%1 düzeyinde önemlidir. Aynı harfle gösterilen ortalamalar arasında fark yoktur. Öd: önemli değil, Ort: Ortalama. 
Yıl ortalamalarına göre yaş glüten içeriği değeri ikinci yıl elde edilen ortalama değeri birinci yıl ortalamasına göre oldukça yüksek bulunmuştur. Araştırmada genotiplerin yıl ortalamalarına göre en yüksek yaş glüten değeri G6 hattında (\%40.38) elde edilirken, en düşük değer G1 genotipinde (\%34.42) elde edilmiştir. Nişasta içeriği bakımından en yüksek değer araştırmanın yürütüldüğü birinci yılda G1'de (\%63.24) gözlemlenirken, en düşük ortalama değer ise ikinci yılda G6'da (\%59.3) elde edilmiştir. Genotiplerin yıl ortalaması \% 60.57 (G6) - 61.93 (G1) değerleri arasında değişim gösterdiği görülmüştür. Makarnalık buğdayda tanenin renk özelliği irmik ve makarna kalitesini belirlemede önemli bir ölçüt olarak kullanımından dolayı makarna ve irmik yapımı için karakteristik bir özelliktir (Kılıç ve ark., 2012; Kızılgeçi ve ark., 2016). $b$ değeri en yüksek 2016-17 üretim döneminde G4 genotipinde (16.53) gözlemlenirken, en düşük $b$ değeri 2015-16 üretim döneminde FIrat-93'te (14.65) elde edilmiştir. Genotiplerin yıl ortalamalarına göre en yüksek $b$ değeri 16.32 ile G4 genotipinde, en düşük ise 15.01 ile Fırat 93 çeşidinde elde edilmiştir. $b$ değeri ile ilgili yapılan çalışmalarda Akcura (2009) 16.24-18.83, Kılıç ve ark. (2012) 17.6-26.1, Tekdal ve ark. (2014) 22.727.8 ve Kızılgeçi ve ark. (2016)14.92-16.71 değerlerini elde ettiklerini bildirmişlerdir. Íkinci yılda incelenen kalite özelliklerinden protein içeriği ve yaş gluten için koşulların uygun olduğu görülmüştür. Buğdayın, tane dolum döneminde protein içeriği ve yaş gluten içeriği değerinin yağışlı dönemlerde azalmakta kurak geçen dönemlerde artmaktadır. Çalışmamızda tane dolum döneminde
2016-17 sezonunda havanın nisbi neminin düşük ve sıcaklığın yüksek oluşu tanede protein içeriği ve yaş gluten içeriğinin yüksek olmasına neden olduğu düşünülmektedir. Birçok araştırmacı tanenin kalite özelliklerinin genotip, agronomik uygulamalara, çevresel koşullara (sıcaklık, toprak yapısı vb.) göre farklılıklar gösterdiğini bildirmişlerdir (Bulut, 2012; Guzman ve ark., 2016; Boehm ve ark., 2017; Türköz ve Mut, 2017; Oral ve ark., 2018). G6 hattı her iki üretim sezonunda tanenin kalite özellikleri yönünden ön plana çıkan genotip olmuştur. Kalite özellikleri ile fizyolojik özellikler arasındaki ilişkiler incelendiğinde 2015-16 üretim sezonunda yaş gluten ile SPAD arasında olumlu ve önemli ( $r=$ $0.373)$, protein içeriği ile BÖS arasında olumlu ve önemli $\left(r=0.384^{*}\right)$ görülmüştür. $b$ değeri ile SPAD ve NDVI ile arasında olumlu ve önemli ( $r=0.422 *$ ve 0.375*, sırasıyla) ilişki belirlenmiştir. 2016-17 üretim sezonunda protein içeriği ve yaş gluten ile SPAD arasında olumlu ve önemli ( $r=0.596^{*}$ ve $0.733^{*}$, sırasıyla) ilişki belirlenirken, nişasta içeriği ile olumsuz ve önemli $\left(r=-0.460^{* *}\right)$ ilişki belirlenmiştir. Yaş gluten ile NDVI arasında olumsuz ve önemli ( $r=-0.350$ ) ilişki belirlenmiştir (Çizelge 3).

\section{Fizyolojik özellikler}

Başaklanma döneminde makarnalık buğday genotiplerinde ölçülen SPAD, BÖS, NDVI ve LAI'ye ait değerler Çizelge 5 'te verilmiştir. SPAD, BÖS ve NDVI özellikleri yönünden genotip, yıl ve genotip $x$ yıl interaksiyonu istatistiki olarak önemli farklılıklar belirlenirken, LAI özelliğinde ise sadece yıllar arasında farklılıklar belirlenmiştir (Çizelge 5).

Çizelge 5. Farklı yıllarda yetiştirilen durum buğday genotiplerinin SPAD, BÖS, NDVI, LAI değerleri

\begin{tabular}{|c|c|c|c|c|c|c|c|c|c|c|c|c|}
\hline \multirow{2}{*}{ Genotip } & \multicolumn{3}{|c|}{ SPAD } & \multicolumn{3}{|c|}{ BÖS } & \multicolumn{3}{|c|}{ NDVI } & \multicolumn{3}{|c|}{ LAI } \\
\hline & 2015-16 & $2016-17$ & Ort. & 2015-16 & 2016-17 & Ort. & 2015-16 & 2016-17 & Ort & $2015-162$ & $2016-17$ & Ort. \\
\hline CESARE & $49.8^{\text {de }}$ & $49.7^{b c}$ & $49.8^{b}$ & $21.50^{d}$ & $26.15^{a b c}$ & $23.83^{b c}$ & $0.83^{\mathrm{abc}}$ & $0.49^{b c}$ & $0.66^{\mathrm{ab}}$ & $2.85^{c}$ & $3.68^{\mathrm{a}}$ & 3.26 \\
\hline FIRAT93 & $48.3^{\mathrm{fg}}$ & $45.0^{\mathrm{e}}$ & $46.7^{c}$ & $21.53^{d}$ & $25.73^{\mathrm{bcd}}$ & $23.63^{b c}$ & $0.78^{d}$ & $0.50^{b}$ & $0.64^{\mathrm{cd}}$ & $3.28^{\mathrm{abc}}$ & $2.88^{\mathrm{ef}}$ & 3.08 \\
\hline G1 & $49.5^{\mathrm{ef}}$ & $48.9^{c}$ & $49.0^{b}$ & $21.65^{\mathrm{cd}}$ & $26.35^{\mathrm{ab}}$ & $24.00^{b c}$ & $0.83^{\mathrm{ab}}$ & $0.47^{c}$ & $0.65^{b c}$ & $3.00^{b c}$ & $3.43^{\mathrm{ab}}$ & 3.21 \\
\hline $\mathrm{G} 2$ & $53.6^{a}$ & $45.6^{e}$ & $49.6^{b}$ & $22.15^{b c}$ & $27.30^{\mathrm{a}}$ & $24.73^{a}$ & $0.78^{d}$ & $0.55^{a}$ & $0.66^{a}$ & $3.38^{\mathrm{ab}}$ & $3.28^{\mathrm{a}-\mathrm{e}}$ & 3.33 \\
\hline G3 & $50.9^{\mathrm{cd}}$ & $49.3^{b c}$ & $50.1^{b}$ & $22.20^{\mathrm{ab}}$ & $25.95^{b c}$ & $24.08^{a b c}$ & $0.78^{d}$ & $0.53^{a}$ & $0.65^{a b c}$ & $2.85^{c}$ & $3.20^{b-f}$ & 3.03 \\
\hline G4 & $52.9^{\mathrm{ab}}$ & $50.9^{a b}$ & $51.9^{a}$ & $22.25^{\mathrm{ab}}$ & $24.98^{c d}$ & $23.61^{b c}$ & $0.84^{a}$ & $0.42^{d}$ & $0.63^{d}$ & $3.45^{\mathrm{ab}}$ & $2.93^{\text {def }}$ & 3.19 \\
\hline G5 & $49.6^{\text {def }}$ & $48.2^{\mathrm{cd}}$ & $48.9^{b}$ & $22.25^{\mathrm{ab}}$ & $25.43^{\mathrm{bcd}}$ & $23.84^{b c}$ & $0.81^{c}$ & $0.49^{b c}$ & $0.65^{b c}$ & $3.25^{a b c}$ & $3.30^{a-d}$ & 3.28 \\
\hline G6 & $47.4^{\mathrm{g}}$ & $52.4^{\mathrm{a}}$ & $49.9^{b}$ & $22.73^{a}$ & $25.83^{\mathrm{bcd}}$ & $24.28^{\mathrm{ab}}$ & $0.85^{a}$ & $0.48^{b c}$ & $0.66^{\mathrm{ab}}$ & $3.33^{\mathrm{ab}}$ & $3.00^{c-f}$ & 3.16 \\
\hline G7 & $52.0^{\mathrm{bc}}$ & $46.0^{\mathrm{de}}$ & $49.0^{b}$ & $22.20^{\mathrm{ab}}$ & $24.75^{d}$ & $23.48^{c}$ & $0.81^{b c}$ & $0.49^{b c}$ & $0.65^{b c}$ & $3.53^{\mathrm{a}}$ & $3.48^{\mathrm{ab}}$ & 3.5 \\
\hline Ortalama & $50.5^{a}$ & $48.4^{b}$ & 49.4 & $22.05^{b}$ & $25.83^{a}$ & 23.93 & $0.81^{a}$ & $0.49 \mathrm{~b}$ & 0.64 & 3.21 & 3.24 & 3.22 \\
\hline LSD YII & & $0.60 * *$ & & & $0.32 * *$ & & & $0.01^{* *}$ & & & $0.42 * *$ & \\
\hline LSD Genotip & & $1.30 * *$ & & & $0.66^{*}$ & & & $0.01 * *$ & & & öd & \\
\hline LSD YılxGen & & $1.84 * *$ & & & $0.96 * *$ & & & $0.02 * *$ & & & öd & \\
\hline
\end{tabular}

*,** sırasıyla \%5, \%1 düzeyinde önemlidir. Aynı harfle gösterilen değerler aynı grupta yer almıştır. Öd: önemli değil. 
Çalışmamızda en yüksek SPAD değeri birinci yılda G2 hattında (53.6) belirlenirken en düşük ortalama değer ise ikinci yılda Fırat-93 çeşidinde (45.00) gözlemlenmiştir. Genotiplerin yıl ortalamalarına göre 51.9 ile G4 hattında belirlenirken en düşük değer 46.7 ile Fırat 93 çeşidinde belirlenmiştir. Kızılgeçi ve ark. (2017) bitkide klorofil içeriği değerinin yüksek olması arzu edilen bir özellik olduğunu ve bayrak yaprak klorofil içeriği uygun koşullarda yüksek olan genotiplerin daha fazla fotosentez kapasitesine ve daha yüksek tane verimine sahip olacağını belirtmişlerdir. Birçok araştırmacı başaklanma ve tane dolum döneminde ölçülen klorofil içeriği değeri ile tane verimi arasında olumlu ilişki olduğu bildirilmiştir (Bavec ve Bavec, 2001; Yıldırım ve ark., 2009; Yıldırım ve ark., 2010; Kendal, 2015).

Bitki örtü sıcaklığı (BÖS) değeri bitkinin kendini sıcaklık stresine karşı serinletme reaksiyonu olarak ifade edilmektedir. Sıcaklık stresinin olduğu durumlarda bu değerin düşük olması istenilmektedir. Çalışmada en yüksek BÖS değeri ikinci yılda G2 hattında (27.3 oC) elde edilirken en düşük ortalama değer ise birinci yılda Cesare (21.5 oC) çeşidinde saptanmıştır. Başaklanma döneminde 2016-17 sezonunda hava sıcaklığının 2015-16 sezonuna göre yüksek olması nedeniyle BÖS değeri ikinci yılda yetiştirilen genotiplerde yüksek bulunmuştur. Çalışmamızda ikinci yılda en yüksek tane verimi değerine sahip olan G7 genotipi en düşük bitki örtüsü sıcaklığı değerine sahip olmuştur. Talebi (2011) kuraklığa toleranslı hatların geliştirilmesinde ve değerlendirilmesinde bitki örtüsü sıcaklığı özelliğinin kuraklığa yüksek dayanımlı makarnalık buğday geliştirmede etkili biçimde kullanılabileceğini bildirmiştir. Munjal ve Rana (2003) yüksek sıcaklık stresine dayanımda BÖS değerinin önemli bir fizyolojik belirleyici olduğunu belirtmişlerdir.

Araştırmada en yüksek NDVI değeri birinci yılda G6 hattında (0.85) en düşük ortalama değer ise ikinci yılda G4 hattında (0.42) gözlemlenmiştir. NDVı değerleri kıyaslandığında, ikinci yılda elde edilen değerlerin düşük olduğu görülmektedir.

LAI değeri bakımından en yüksek değer araştırmanın yürütüldüğü ilk yılda Cesare çeşidinde (3.68) ve en düşük ortalama değer ise birinci yılda G3'te (2.85) elde edilmiştir. LAI değeri tür ve çeşide göre değişmekle birlikte bitkinin gelişim dönemlerine göre de farklılık göstermektedir (Kızılgeçi ve ark., 2017). Çalışmamızda LAI değeri ile tane verimi arasında önemli bir ilişki saptanmamıştır. Yıldırım ve ark. (2018b) LAI değerinin düşük veya yüksek olmasından daha çok her genotip için uygun değerlerin belirlenmesinin önemli olduğunu ve yem değeri yönünden yüksek
LAl değerine sahip çeşitlerin tercih edilmesi gerektiğini bildirmiştir.

\section{Sonuç ve Öneriler}

Çalışmanın sonucunda; Cesare ve G7 makarnalık buğday genotipleri tane verimi ve kalite özellikleri bakımından diğer genotiplere göre daha iyi performans göstermişlerdir. Makarnalık buğdayın başaklanma döneminde ölçülen fizyolojik ölçümler ile tane verimi ve kalite özellikleri arasındaki ilişkiler yıllara göre farklılık göstermiştir. Her iki üretim sezonunda ölçülen SPAD değeri ile protein içeriği ve yaş gluten arasında olumlu ilişkiler bulunması SPAD'ın ıslahta kaliteli genotip geliştirmede seleksiyon kriteri olarak değerlendirilebileceğini ve bu yönde daha kapsamlı araştırmalar yapılması gerektiğini düşündürmektedir.

\section{Kaynaklar}

Akcura, M. 2009. Genetic variability and interrelationship among grain yield and some quality traits in Turkish winter durum wheat landraces. Turkish Journal of Agriculture and Forestry, 33(6): 547-556.

Bavec, F., Bavec, M. 2001. Chlorophyll meter readings of winter wheat cultivars and grain yield prediction. Commun Soil Sci Plant Anal., 32: 2709-2719.

Boehm, J.D., Ibba, M.I., Kiszonas, A.M., Morris, C.F. 2017. End-use quality of CIMMYT-derived soft-kernel durum wheat germplasm: I. Grain, milling, and soft wheat quality. Crop Science, 57(3): 1475-1484.

Bouacha, O.D., Nouaigui, S., Rezgui, S. 2014. Effects of $\mathrm{N}$ and $\mathrm{K}$ fertilizers on durum wheat quality in different environments. Journal of Cereal Science, 59(1): 9-14.

Bulut, S. 2012. Ekmeklik buğdayda kalite. Erciyes Üniversitesi Fen Bilimleri Enstitüsü Fen Bilimleri Dergisi, 28(5): 441-446.

Çölkesen, M. 1993. Buğday ve arpada kalitenin belirlenmesi. Harran Üniv. Zir. Fak. Derg., 4(1): 115-128.

Fischer, R.A., Rees, D., Sayre, K.D., Lu, Z.M., Condon, A.G., Larque-Saavedra. A. 1998. Wheat yield progress is associated with higher stomatal conductance and photosynthetic rate, and cooler canopies. Crop Sci., 38: 1467-1475.

Giunta, F., Motzo, R., Deidda, M. 2002. SPAD readings and associated leaf traits in durum wheat, barley and triticale cultivars. Euphytica, 125(2): 197- 205.

Guzman, C., Autrique, J.E., Mondal, S., Singh, R.P., Govindan, V., Morales-Dorantes , A., Posadas-Romano, G., Crossa, J., Ammar, K., 
Peña, R.J. 2016. Response to drought and heat stress on wheat quality, with special emphasis on bread-making quality, in durum wheat. Field Crops Research, 186: 157-165.

Huseynova, I.M., Rustamova, S.M. 2010. Screening for drought stress tolerance in wheat genotypes using molecular markers. Proc. ANAS (Biol. Sci.), 65: 132-139.

Islam, M.R., Haque, K.M.S., Akter, N., Karim, M.A. 2014. Leaf chlorophyll dynamics in wheat based on SPAD meter reading and its relationship with grain yield. Sci Agric, 4: 1318.

Kaya, Y., Akcura, M. 2014. Effects of genotype and environment on grain yield and quality traits in bread wheat (Triticum aestivum L.). Food Sci. Technol. Campinas, 34: 386-393.

Kendal, E. 2015. Relationship between chlorophyll and other features in durum wheat (Triticum turgidum L. var. durum) using SPAD and biplot analyses. J. Agr. Sci. Tech., 17: 1873-1886.

Kılıç, H. 2003. Güneydoğu Anadolu Bölgesi Koşullarında Makarnalık Buğday (Triticum turgidum ssp. durum) Çeşitlerinin Bazı Tarımsal ve Kalite Özellikleri ile Stabilitesi Üzerine Araştırmalar. Doktora Tezi, Çukurova Üniversitesi Fen Bilimleri Enstitüsü.

Kılıç, H., Tekdal, S., Kendal, E., Aktaş, H. 2012. Augmented deneme desenine dayalı ileri kademe makarnalık buğday (Triticum turgidum ssp.) hatlarının biplot analiz yöntemi ile değerlendirilmesi. KSÜ Doğa Bilimleri Dergisi, 15(4): 18-25.

Kızılgeçi, F., Yıldııım, M., Akıncı, C., Albayrak, Ö., Başdemir, F. 2015. İleri kademe makarnalık bugday popülasyonlarının verim ve kalite yönünden seleksiyonda kullanılabilirliği. Süleyman Demirel Üniversitesi Ziraat Fakültesi Dergisi, 10(2): 62-68.

Kızılgeçi, F., Akıncı, C., Biçer, B.T., Albayrak, Ö., Yıldırım, M. 2016. Tane rengi ve protein miktarı yönünden F5 makarnalık buğday (Triticum durum Desf.) populasyonlarının değerlendirilmesi. Dicle Üniversitesi Fen Bilimleri Enstitüsü Dergisi, 5(2): 51-55.

Kızılgeçi, F., Akıncı, C., Albayrak, Ö., Yıldırım, M. 2017. Tritikale hatlarında bazı fizyolojik parametrelerin verim ve kalite özellikleriyle ilişkilerinin belirlenmesi. Iğdır Üniversitesi Fen Bilimleri Enstitüsü Dergisi,7(1): 337344.

Li, Y., Wu, Y., Hernandez-Espinoza, N., Pena, R.J. 2013. The influence of drought and heat stress on the expression of end-use quality parameters of common wheat. J. Cereal Sci., 57:73-78.

Lopes, M.S., Reynolds, M.P., Jalal-Kamali, M.R., Moussa, M., Feltaous, Y., Tahir I.S.A. 2012. The yield correlations of selectable physiological traits in a population of advanced spring wheat lines grown in warm and drought environments. Field Crops Res., 128: 129-136.

Mohammadi, M. 2012. Effects of kernel weight and source-limitation on wheat grain yield under heat stress. Afri. J. Biotechnol., 11: 2931-2937.

Munjal, R., Rana, R.K. 2003. Evaluation of physiological traits in wheat (Triticum aestivum L.) for terminal high temperature tolerance. Proceedings of the tenth international wheat genetics symposium, 16 September, Poestum, Italy, 2: 804-805.

Oral, E., Kendal, E., Doğan, Y. 2018. Bazı durum buğday çeşitlerinin biplot ve AMMI (ana etkiler ve çarpımsal interaksiyonlar) analizleri ile stabilitelerinin belirlenmesi. Journal of Bahri Dagdas Crop Research, 7(1): 1-13.

Ozkan, H., Willcox, G., Graner, A., Salamini, F., Kilian, B. 2011. Geographic Distribution and Domestication of Wild Emmer Wheat (Triticum dicoccoides). Genetic Res. Crop Evol., 58(1): 11-53.

Pinto, R.S., Reynolds, M.P., Mathews, K.L., Mclntyre, C.L., Olivares-Villegas, J.J., Chapman, S.C. 2010. Heat and drought adaptive QTL in a wheat population designed to minimize confounding agronomic effects. Theoretical and Applied Genetics, 121(6): 1001-1021.

Schuhwerk, D. 2011. Field-screening of durum wheat ( $T$. durum Desf.) for drought tolerance. Department of crop science, University of Natural Resources and Life Science, Vienna, Wien.

Talebi, R. 2011. Evaluation of chlorophyll content and canopy temperature as indicators for drought tolerance in durum wheat (Triticum durum Desf.). Aust. J. Basic Appl. Sci., 5: 1457-1462.

Tekdal, S., Kendal, E., Ayana, B. 2014. İleri kademe makarnalık buğday hatlarının verim ve bazı kalite özelliklerinin biplot analiz yöntemi ile değerlendirilmesi. Türk Tarım ve Doğa Bilimleri Dergisi, 1(3): 322-330.

Tekdal, S., Yıldırım, M. 2017. Bazı makarnalık buğday genotiplerinde fizyolojik ve morfolojik parametrelerin sıcaklık stresi ile ilişkisi. Tr. Doğa ve Fen Derg., 6(2): 72-78. 
TÜik, 2018. Türkiye İstatistik Kurumu. https://tuik.gov.tr/medas/?kn=92\& locale=tr, [Erişim:10.12.2018].

Türköz, M.,Mut, Z. 2017. Konya ekolojisinde bazı makarnalık buğday genotiplerinin verim ve kalite özelliklerinin belirlenmesi. Selçuk Tarım ve Gıda Bilimleri Dergisi, 31(2): 27-36.

Yıldırım, M., Akıncı, C., Koç, M., Barutçular, C. 2009. Bitki örtüsü serinliği ve klorofil miktarının makarnalık buğday ıslahında kullanım olanakları. Anadolu Tarım Bilimleri Dergisi, 24(3): 158-166.

Yıldırım, M., Kılıc, H., Kendal, E., Karahan, T. 2010. Applicability of chlorophyll meter readings as yield predictor in durum wheat. J. Plant Nutr., 34: 151-164.

Yıldırım, M., Barutçular, C, Koc, M., Dizlek, H., El Sabagh, A., Hossain, A., Islam, M.S., Toptas, I., Basdemir, F., Albayrak, O., Akinci, C. 2018a. Assessment of the grain quality of wheat genotypes grown under multiple environments using GGE biplot analysis. Fresenius Environmental Bulletin, 27(7): 4830-4837.

Yıldırım, M., Kızılgeçi, F., Akıncı, C., Albayrak, Ö. 2018b. Ekmeklik buğday genotiplerinin başaklanma döneminde ölçülen LAI, SPAD, NDVI, BÖS ile tane verimi ve kalite özelikleri arasında korelasyon analizi. Anadolu I. Uluslararası Multidisipliner Çalışmalar, 2829 Aralık, Diyarbakır, s. 853-857. 